\title{
PROSTITUSI DALAM PERSPEKTIF HAK ASASI MANUSIA DAN ISLAM (STUDI KASUS PRAKTEK PROSTITUSI DI KOTA BENGKULU)
}

\author{
John Kenedi \\ Fakultas Syariah IAIN Bengkulu \\ J. Raden Fatah Pagar Dewa Bengkulu \\ Email: johnkenedi297@yahoo.com
}

\begin{abstract}
Prostitution is a community disease that is difficult to eradicate due to many factors that affect its existence. The various types of prostitution that emerged show how prostitution has grown in society. The condition is further complicated when prostitution seeks to seek protection under human rights. Prostitution seeks the path of protection under human rights through two essentials: Protection of human rights to the work of sex workers and protection of minority status opposed by the wider community. On the other hand, there is a distinction between liberal Westernmade human rights and human rights according to Islam in accordance with the sunatullah, so that the distinction raises different perceptions regarding the issue of prostitution. This paper will reveal whether prostitution is a profession that should be protected as a right to work in human rights, as well as finding the right way out to avoid conflict of interest in human rights so that peace and tranquility can be realized in society.
\end{abstract}

Keywords: Prostitution, Human Rights

\begin{abstract}
Abstrak: Prostitusi merupakan penyakit masyarakat yang sulit untuk diberantas karena banyak faktor yang mempengaruhi eksistensinya. Beragam tipe prostitusi yang muncul menunjukkan betapa perkembangan prostitusi telah menggurita di dalam masyarakat. Kondisi tersebut semakin rumit ketika prostitusi berupaya mencari perlindungan di bawah hak asasi manusia. Prostitusi mencari jalan perlindungan di bawah hak asasi manusia melalui dua hal yang esensial yaitu: perlindungan hak asasi manusia terhadap pekerjaan para pekerja seks, dan perlindungan terhadap status minoritas yang ditentang oleh masyarakat luas. Pada sisi yang lain, terdapat perbedaan antara hak asasi manusia bentukan barat yang serba liberal dengan hak asasi manusia menurut Islam yang sesuai dengan sunatullah, sehingga perbedaan tersebut menimbulkan persepsi yang berbeda pula berkenaan dengan persoalan prostitusi. Tulisan ini akan mengungkap apakah prostitusi merupakan profesi yang patut dilindungi sebagai right to work (hak berprofesi) dalam hak asasi manusia, sekaligus menemukan jalan keluar yang tepat untuk menghindari benturan kepentingan dalam hak asasi, sehingga kedamaian dan ketenteraman dapat terwujud di dalam masyarakat.
\end{abstract}

Kata kunci: prostitusi, hak asasi manusia

\section{Pendahuluan}

Kata "prostitusi" berasal dari bahasa latin prostuera atau prostaure yang artinya membiarkan diri berbuat zina, melakukan persundalan, dan pencabulan. Pelaku kegiatan prostitusi atau pelacuran dikenal pula dengan istilah Wanita Tuna Susila (WTS), Pekerja Seks Komersil (PSK) atau pelacur. ${ }^{1}$ Kartini Kartono menyebutkan bahwa prostitusi terjadi dikarenakan beberapa

${ }^{1}$ Kartini Kartono, Patologi Sosial, (Jakarta: RajaGrafindo Persada, 1992), h. 117. faktor yaitu: Ketiadaan undang-undang yang melarang pelacuran—sedang yang dilarang dan diancam hukuman adalah praktek germo (Pasal $296 \mathrm{KUHP}^{2}$ ) dan mucikari (Pasal $506 \mathrm{KUHP}^{3}$ );

2 "Barangsiapa dengan sengaja menghubungkan atau memudahkan perbuatan cabul oleh orang lain dengan orang lain, dan menjadikannya sebagai pencarian atau kebiasaan, diancam dengan pidana penjara paling lama satu tahun empa bulan atau denda paling banyak seribu rupiah". Moeljatno, Kitab Undang Undang Hukum Pidana (KUHP), (Jakarta: Bumi Aksara, 2001), h. 108-109.

3 "Barangsiapa menarik keuntungan dari perbuatan cabul seorang wanita dan menjadikan sebagai pencarian, diancam 
dan adanya keinginan dan dorongan manusia untuk menyalurkan kebutuhan seks, khususnya di luar ikatan perkawinan. ${ }^{4}$

Ahli hukum berpendapat bahwa prostitusi tidak selalu dilakukan oleh dua orang atau lebih yang berbeda jenis kelamin dan dilakukan di luar nikah, serta dengan imbalan transaksional. Namun, aktifitas prostitusi dapat juga melibatkan sesama jenis-seperti homoseksual dan lesbian-dengan catatan kegiatan itu diikuti dengan pembayaran. ${ }^{5}$ AS. Alam mengatakan bahwa terdapat beberapa tipe prostitusi, yakni: Prostitusi jalanan (street prostitution) atau prostitusi kelas rendahan yang biasanya sering dijumpai di jalanan pada malam hari, dan prostitusi panggilan (call girl prostitution) yang dijajakan melalui mucikari/induk semang yang disebut "mami" sebagai perantara, pelacuran rumah bordil (brothel prostitution) baik yang resmi maupun yang liar, prostitusi terselubung (clanddestine prostitution) yang menggunakan kedok dalam aksinya, dan prostitusi amatir yang bersifat rahasia. ${ }^{6}$

Prostitusi di Bengkulu berkembang pesat sejalan dengan perkembangan kota. Baik prostitusi terselubung maupun yang terbuka, keduanya mendapat tempat dalam kota penting yang menjadi bagian sejarah bangsa Indonesia itu. Para penyedia jasa layanan seks tersebut seakan-akan tidak ada rasa malu lagi terhadap profesi yang dijalaninya. Saking banyaknya Pekerja Seks Komersil (PSK) di kota yang berjuluk Bumi Raflesia ini, keseluruhannya dapat diklasifikasi menjadi tiga bagian yakni: Prostitusi kelas rendah, prostitusi kelas menengah, hingga prostitusi kelas atas.

Banyak kalangan yang menganggap bahwa prostitusi adalah penyakit masyarakat yang harus dibasmi, sementara kalangan yang lainnya

dengan kurungan paling lama satu tahun”. Moeljatno, Kitab..., h. 184 .

${ }^{4}$ Moeljatno, Kitab..., h. 206.

5 John Kenedi, "Pers dan Prostitusi", Bengkulu Ekspress, Tahun ke-2, Minggu 20 Februari 2000, h. 2.

${ }^{6}$ AS. Alam, Pelacuran dan Pemerasan Studi Sosiologis Tentang Exploitasi Manusia Oleh Manusia, (Bandung: Alumni, 1984), h. 53. John Kenedi, "Pers dan Prostitusi", Bengkulu Ekspress, Tahun ke-2, Minggu 20 Februari 2000, h. 2. berpendapat bahwa prostitusi harus dikelola dengan profesional atas dasar perlindungan terhadap hak asasi manusia. Pengelolaan tersebut dianggap sebagai jalan tengah terhadap persoalan prostitusi di Kota Bengkulu. Jalan tengah yang dianggap efektif mencegah praktik prostutusi liar sekaligus menghindari potensi konflik dengan oknum-oknum berduit yang menganggap prostitusi sebagai sarana rekreasi mereka.

Saat ini prostitusi juga menjadi "senjata politik" yang dapat digunakan dalam memuluskan suatu tujuan. Gratifikasi seksual dapat ditawarkan kepada oknum-oknum tertentu manakala gratifikasi harta benda menemui jalan buntu guna melicinkan proyek-proyek strategis. Gratifikasi yang awalnya hanya diidentikkan dengan uang dan barang sekaran telah berubah bentuk menjadi gratifikasi layanan seksual. Pelayanan semacam itu sudah ada sejak lama dan terus berlangsung hingga kini. ${ }^{7}$

Kemudian yang menjadi persoalan ialah apakah betul prostitusi merupakan profesi yang patut dilindungi sebagai right to work (hak berprofesi) ${ }^{8}$ dalam hak asasi manusia? Lantas bagaimanakah pandangan hak asasi dalam Islam menyoal prostitusi? serta apa jalan keluar dari seluruh persoalan ini? Problematika benturan hak asasi ini perlu dicarikan jalan keluarnya, sehingga kedamaian dan ketenteraman dapat terwujud di dalam masyarakat.

\section{Dialektika Dogmatik Agama dan Doktrin Hak Asasi Manusia}

Hak asasi manusia adalah seperangkat hak yang melekat pada hakikat manusia sebagai makhluk Tuhan yang Maha Esa dan merupakan anugerah-Nya yang wajib dihormati, dijunjung tinggi, dan dilindungi oleh negara hukum, pemerintahan, dan setiap orang, demi

${ }^{7}$ M. Nurul Irfan, Gratifikasi \& Kriminalitas Seksual dalam Hukum Pidana Islam, (Jakarta: Amzah, 2014), h. 56-57.

${ }^{8}$ Right to work adalah salah satu dari sebelas hak yang terangkum dalam socio economic rights. Nurul Qamar, Hak Asasi Manusia dalam Negara Hukum Demokrasi (Human Rights in Democratiche Rechtstaat, (Jakarta: Sinar Grafika, 2013), h. 98. 
kehormatan serta perlindungan harkat dan martabat manusia. ${ }^{9}$

Menurut Deklarasi Universal Hak Asasi Manusia (DUHAM), terdapat lima jenis hak asasi yang dimiliki oleh setiap individu yaitu: Hak personal (hak jaminan kebutuhan pribadi), hak legal (hak jaminan perlindungan hukum), hak subsistensi (hak jaminan adanya sumber daya untuk menunjang kehidupan), dan hak ekonomi, sosial, serta budaya. ${ }^{10}$ Secara terperinci Pasal 1 dan Pasal 2 menjelaskan hal-hal umum antara lain bahwa semua manusia dilahirkan merdeka dan mempunyai martabat dan hak yang sama. Pasal 3 hingga Pasal 21 bersubstansikan hak sipil dan politik seperti hak hidup, hak kebebasan berpendapat, hak berorganisasi, hak untuk memilih dan dipilih, serta hak untuk duduk dalam pemerintahan. Selanjutnya Pasal 22 sampai Pasal 27 mengemukakan tentang hakhak ekonomi, sosial, dan kebudayaan seperti hak atas pekerjaan, hak jaminan sosial, dan hak mempertahankan atau mengembangkan kebudayaan. Terakhir, Pasal 28 sampai Pasal 30 merupakan pasal penutup yang menyatakan bahwa setiap manusia berhak atas tata sosial dan tata internasional sebagai tempat hak-hak dan kebebasan-kebebasan itu terwujud.

Bekerja mencari nafkah atau bermatapencaharian merupakan suatu hak yang diakui oleh negara; menjalankan perintah agama juga merupakan hak lain yang juga termasuk hak-hak yang dijamin oleh pemerintah. Tidak sedikit orang yang menjadi penyedia layanan jasa seksual mengklaim bahwa prostitusi merupakan satu-satunya pekerjaan yang dapat menghidupi mereka dan keluarganya. Namun demikian, di sisi lain banyak pula pihak yang berkeberatan terhadap keberadaan profesi tersebut dikarenakan dampak negatif yang muncul karenanya.

9 Pasal 1 butir 1, Undang Undang Nomor 39 Tahun 1999 tentang Hak Asasi Manusia.

10 A. Ubaedillah, dkk., Pendidikan Kewargaan (Civic Education): Demokrasi, Hak Asasi Manusia, dan Masyarakat Madani, (Jakarta: ICCE UIN Jakarta dan Kencana Prenada Media Group), h. 112-113.
Negara-negara Barat melindungi segala bentuk pekerjaan yang dilakukan oleh setiap orang, tidak peduli apakah pekerjaan tersebut baik atau buruk dalam segi moralitas. ${ }^{11}$ Itulah sebabnya negaranegara tersebut memiliki perbedaan pandangan dengan negara-negara Timur dalam menyikapi prostitusi. Negara-negara Barat cenderung mengedepankan ungkapan "prostitution is not a crime" ketimbang ungkapan "prostitution is a real crime.${ }^{12}$ Di negara-negara Barat, penyedia layanan jasa seks dilindungi dengan undang-undang dan dijamin kebebasannya dalam berpraktik di tempat-tempat yang disediakan oleh pemerintah. Kesehatan para pekerja seks pun dimonitor secara berkala dan diupayakan sanitasinya. Konsepsi yang demikian kemudian menjadi landasan berpikir terbitnya sejumlah peraturan perundangundangan yang kurang menganggap penting suatu perbuatan prostitusi di dalam masyarakat, bahkan ada yang cenderung memfasilitasi bukan membatasi perkembangannya.

Prostitusi dalam pemaknaannya sebagai sebuah profesi dilindungi oleh Deklarasi Universal Hakhak Asasi Manusia (DUHAM), khususnya pada hak untuk bekerja sebagai bagian integral dari hak ekonomi, sosial, dan budaya yang diatur dalam Pasal 22-27..$^{13}$ Bahkan berdasarkan konsepsi hak asasi manusia versi Barat inilah, beberapa peraturan sengaja akan dan telah dibuat untuk mengkhususkan kegiatan prostitusi dengan sebutan lokalisasi. Tujuan dibuatnya lokalisasi itu memiliki alasan agar para PSK tersebut dapat dipantau kondisi dan kesehatannya, sehingga campur tangan pemerintah diharapkan dapat meminimalisir efek jelek yang mungkin akan muncul dari praktik prostitusi. Inilah produk rancangan Barat yang dibungkus dengan dalih hak asasi manusia, melindungi hak asasi para pekerja

\footnotetext{
${ }^{11}$ Negara Inggris merupakan tempat lahirnya Magna Charta yang dianggap sebagai tonggak lahirnya Hak Asasi Manusia sedunia. Konsep hak asasi manusia yang diusung oleh Barat adalah hak asasi yang berpaham liberal.

12 Prostitusi di Barat dianggap bukan sebuah kejahatan, kecuali dilakukan oleh anak-anak di bawah umur. Negaranegara yang menjunjung tinggi liberalisme ini memperbolehkan freesex atas dasar suka sama suka.

${ }^{13}$ Max Boli Sabon, Hak Asasi Manusia, (Jakarta: Atma Jaya, 2014), h. 18.
} 
seks komersil sekaligus melindungi hak asasi para prostituan penikmat layanan jasa seksual. Intinya ialah DUHAM memberikan pengakuan, dan perlindungan, serta fasilitas terhadap profesi yang digeluti oleh para pekerja seks tanpa pengecualian. ${ }^{14}$

Ada juga pendapat yang menyatakan bahwa bekerja dalam bidang prostitusi merupakan pekerjaan golongan minoritas yang layak memperoleh perlindungan. Hal tersebut didasari oleh Konvenan Hak Sipil dan Politik Komite HAM PBB Pasal 27 yang mengakui dan melindungi kelompok minoritas yang berbeda dengan hak orang lain. ${ }^{15}$ Dengan alasan ini, para PSK dan penyedia jasa layanan seks menuntut perlindungan dan jaminan dari pemerintah atas keberadaan mereka.

Dua fenomena di atas tentu tidak sejalan dengan cita-cita keagamaan di Indonesia. Agama apapun, secara keseluruhan menentang praktik prostitusi dan menyepakati bahwa perbuatan itu merupakan kekejian yang mendatangkan dosa bagi pelakunya. Sebagai panduan manusia dalam bertingkah laku, agama mengajarkan setiap manusia untuk menghindari setiap keburukan. Salah satu agama yang paling serius menentang prostitusi adalah agama Islam. Agama Islam mengajarkan bahwa prostitusi merupakan perbuatan haram yang dilarang. Pelaku prostitusi diancam dengan ganjaran dosa besar, kehinaan di dunia, dan siksaan di neraka. Seluruh mazhab dalam Islam menyepakati bahwa prostitusi adalah hubungan badan yang diharamkan dan disengaja oleh pelakunya. ${ }^{16}$ Mengenai kekejian prostitusi ini, Muhammad al-Khatib asy-Syarbini menyatakan bahwa ia tergolong kepada dosa besar yang paling keji, ${ }^{17}$ pun demikian menurut Husain

${ }^{14}$ Moh. Zahid, Agama \& HAM: Dalam Kasus di Indonesia, (Jakarta: Balai Penelitian dan Pengembangan Agama, Departemen Agama Republik Indonesia, 2007), h. 12-13.

15 Ali Khanif, Hukum \& HAM, (Yogyakarta: Laks Bang, 2012), h. 39.

${ }^{16}$ M. Nurul Irfan, Gratifikasi..., h. 59.

17 "Dari Abdullah meriwayatkan, ia berkata, 'Aku bertanya kepada Rasulullah, Dosa apa yang paling besar di sisi Allah? Beliau menjawab, Kamu menjadikan tandingan bagi Allah padahal Dialah yang menciptakan kamu. Aku bertanya lagi, Kemudian dosa apa lagi? Beliau menjawab, Kamu membunuh
al-Dzahabi bahwa perzinahan adalah dosa besar yang kesepuluh. ${ }^{18}$ Tidak ada satu agama pun yang menghalalkannya. Oleh sebab itu, sanksi hukumnya juga sangat keras sebab zina sebagai jarimah mengancam kehormatan dan hubungan nasab. ${ }^{19}$

\section{Hak Asasi Manusia dalam Islam}

Membahas hak asasi mnusia berarti membicarakan dimensi totalitas kehidupan manusia, bukan hanya dikarenakan pemberian masyarakat ataupun kebaikan dari negara. Hak asasi manusia berangkat dari martbatnya sebagai manusia. Menelaah keadaan hak asasi manusia sebenarnya adalah menelaah totalitas kehidupan, sejauhmana kehidupan memberikan tempat yang wajar bagi kemanusiaan. ${ }^{20}$

Hak asasi manusia dalam frame Islam ialah hak yang dimiliki oleh setiap orang yang diakui oleh aturan-aturan agama. Berdasarkan hal di atas, maka tidak semua hak asasi diakui di dalam Islam. Islam telah mengakui hak-hak asasi manusia sejak diterbitkannya Piagam Madinah. Piagam yang dibuat pada zaman Nabi Muhammad saw., tersebut meliputi pengakuan hak hidup, hak kemerdekaan, hak persamaan, hak keadilan, hak persamaan hukum, hak perlindungan dari kezaliman penguasa, hak perlindungan dari penyiksaan, hak untuk berlindung, hak kerja dalam kehidupan sosial, hak minoritas hak kebebasan dalam berpikir dan berbicara, serta hak ekonomi. ${ }^{21}$

Sebagai agama paripurna, Islam sangat menghormati dan meuliakan status ras mnusia. AshShiddiqy sebagaimana dikutip oleh Syafi'i Ma'arif

anakmu karena takut kalau ia akan makan bersamamu. Aku bertanya lagi, Kemudian apa lagi? Beliau menjawab, Kamu berzina dengan istri tetanggamu?." (HR. Bukhari dan Ibnu Hibban)

18 Syamsuddin al-Dzahabi, Kitab al-Kabäir, (Jakarta: Syirkah Dina Mutiara Berkah Utama, t.th.), h. 42.

${ }^{19}$ Syamsuddin al-Dzahabi, Kitab al-Kabaïr, h. 42.

20 Mujaid Kumkelo, dkk., Fiqh HAM: Ortodoksi dan Liberalisme Hak Asasi Manusia dalam Islam, (Malang: Setara Press, 20115), h. 35.

${ }^{21}$ Zainal Abidin Ahmad, Piagam Madinah: Konstitusi Tertulis Pertama di Dunia, (Jakarta: Pustaka Al-Kautsar, 2014), h. 50. 
menyimpulkan bahwa ada tiga kemuliaan yang dianugerahkan Allah swt. kepada manusia tanpa memandang etnis, agama, dan aspirasi politik. Ketiga kemuliaan itu ialah:

1. Kemuliaan pribadi (karamah fardhiyah). Dalam hal ini, Islam memelihara kepribadian maknawi dan kepribadian materil (maddi) manusia;

2. Kemuliaan masyarakat (karamah ijtima'iyah). Dalam hal ini, status persamaan manusia dijamin sepenuhnya;

3. Kemuliaan politik (karamah siyasah). Dalam hal ini, Islam emberikan semua hak-hak politik kepada manusia untuk memilih atau dipilih bagi posisi-posisi politik, karena ia adalah khalifah Tuhan di bumi. ${ }^{22}$

Selain tiga kemuliaan yang menjadi sendi hak asasi manusia, terdapat juga 5 (lima) prinsip hak asasi manusia yang diakui dan dijunjung tinggi di dalam agama Islam. Kelima prinsip tersebut dikenal dengan konsep al-dharuriyyah al-khams atau kulliyat al-khams ${ }^{23}$ yang dapat diuraikan sebagai berikut:

\section{Hifz al-nafs (perlindungan atas hak hidup)}

Perlindungan atas hak hidup atau perlindungan terhadap jiwa merupkan hak yang tidak bisa ditawar. Penerjemahan yang paling elementer dari hak hidup ini dituangkan dalam sistim hukum, yang salah satunya adalah hukum qishash. Dikarenakan kehidupan merupakan sesuatu hal yang sangat niscaya dan tidak boleh dilanggar oleh siapapun, maka barangsiapa yang secara sengaja melanggar kehidupan orang, maka dia harus dihukum setimpal supaya orang itu tidak melakukan hal yang sama di tempat lain;

2. Hifz al-din (perlindungan atas hak beragama) Perlindungan atas hak beragama atau perlindungan terhadap keyakinan diimplemen-

${ }^{22}$ Ahmad Syafi'i Ma'arif, Islam dan Masalah Kenegaraan, (Jakarta: LP3ES, 1985), h. 169.

${ }^{23}$ Ahmad al-Mursi Husain Jauhar, Maqashid Syariah, (Jakarta: Amzah, 2010), h. xi. tasikan dalam ajaran tidak ada paksaan dalam beragama. Oleh karena itu, tidak diperbolehkan ada pemaksaan dalam memeluk agama;

3. Hifz al-'aql (perlindungan atas akal pikiran) Perlindungan atas akal pikiran diterjemahkan dalam perangkat hukum yang sangat substansial, yakni berkenaan dengan haramnya memakan atau meminum sesuatu yang dapat merusak pikiran dan kesadaran;

4. Hifz al-maal (perlindungaan atas kepemilikan) Perlindungan atas kepemilikan atau perlindungan terhadap hak milik direfleksikan dengan diharamkannya perbuatan mencuri harta milik orang lain. Bilamana diterjemahkan lebih jauh, maka hak ini dapat diartikan pula sebagai hak bekerja atau memperoleh pendapatan yang layak dan seterusnya;

5. Hifz al-nasl (perlindungan atas keturunan dan nama baik)

Perlindungan atas keturunan dan nama baik ini diterjemahkan ke dalam hukum fiqh yang sangat keras terhadap perbuatan zina disebabkan merusak nasab dan nama baik di dalam masyarakat. ${ }^{24}$

Hifz al-nafs adalah alasan pertama penolakan terhadap prostitusi dikarenakan protitusi dapat merusak kehidupan. Tidak hanya merusak kehidupan pelaku prostitusi (pekerja seks) dan prostituant (penikmat jasa layanan seks) saja, namun ia juga dapat merusak keluarga masing-masing pihak yang terlibat di dalamnya. Berbagai penyakit seperti penularan HIV (AIDS), penyakit sipilis (raja singa), herpes, dan penyakit lainnya dapat ditularkan melalui aktifitas prostitusi. Berbagai macam penyakit mematikan sebagai konsekuensi dari freesex jelasjelas menjadi ancaman jiwa yang paling besar. Belum lagi dampak lanjutan dari prostitusi yang lainnya, misalnya perkelahian antara prostituant yang memperebutkan jasa seorang PSK, bahkan tindakan bunuh diri anggota keluarga

\footnotetext{
${ }^{24}$ Mujaid Kumkelo, dkk., Op. Cit., h. 48-49.
} 
yang mungkin saja timbul sebagai akibat dari rusaknya ketenteraman di dalam keluarga.

Prostitusi merupakan perbuatan yang tidak sejalan dengan hifz al-din (perlindungan atas hak beragama). Prostitusi dapat merusak pemahaman seseorang dalam beragama dengan menafikan pernikahan dan melanggar sunatullah. Selain dapat mempengaruhi seseorang sehingga ketergantungan dalam perbuatan prostitusi, perbuatan dosa tersebut dapat juga diartikan sebagai bentuk penentangan terhadap fitrah manusia dalam kehidupan beragama.

Dalam perspektif hifz al-'aql (perlindungan atas akal pikiran), prostitusi ditentang karena dapat membius dan membuat pelakunya menjadi terlena dalam kehidupan. Mengingat kedekatan prostitusi dan minuman keras beserta derivasinya, maka perbuatan tersebut dihukumi haram oleh agama Islam. Sedangkan uang yang dihambur-hamburkan demi meraih kenikmatan sesaat tersebut jelas bertentangan dengan tujuan keempat Islam yaitu: hifz al-maal (perlindungan atas kepemilikan). Harta yang sesungguhnya merupakan titipan Allah swt., kepada manusia guna dimanfaatkan untuk kebutuhan hidup menjadi diselewengkan akibat pemanfaatannya di jalan yang salah.

Hifzal-nasl (perlindungan atas keturunan dan nama baik) merupakan cita-cita terakhir dalam perlindungan Islam terhadap manusia. Prostitusi yang merupakan perbuatan zina tersebut membuat pelaku yang menggandrunginya kehilangan selera untuk membina rumah tangga secara resmi, sebab seluruh kebutuhan batinnya telah terpenuhi oleh layanan jasa seks yang tersedia di berbagai tempat prostitusi. Akibatnya, dari perbuatan tersebut tidak terlahir generasigenerasi selanjutnya yang dapat meneruskan tugas-tugas agama yang mulia yakni menjadi khalifah di atas muka bumi ini.

Pemahaman yang baik terhadap keempat bentuk perlindungan di atas dapat menghadang dan membatasi perkembangan prostitusi di dalam masyarakat muslim.

\section{Solusi yang Berpihak kepada Hak Pelaku Prostitusi dan Hak Masyarakat}

Berdasarkan uraian di atas, maka dapat diambil sebuah konklusi bahawa prostitusi sesungguhnya dapat merusak berbagai sendi kehidupan beragama. Tidak hanya merusak agama itu sendiri, namun juga dapat merusak nasab, merusak harta serta berpotensi merusak akal dan jiwa.

Betapa buruknya dampak dari prostitusi, mau tidak mau setiap orang harus menerima bahwa prostitusi merupakan fakta yang telah terjadi di tengah-tengah masyarakat. Menyalahkan prostitusi saja tanpa memberikan solusi demi perbaikannya jelas merupakan sebuah langkah yang keliru. Sehingga menurut hemat penulis, diperlukan konsep yang baik dan benar dalam menyikapinya sehingga mendatangkan kebaikan dari berbagai pihak.

Wacana pembentukan lokalisasi baik di satu atau dua tempat, sebagaimana yang pernah mencuat beberapa tahun silam bukanlah jalan keluar yang bijak. Tidak ada jaminan bahwa dengan adanya lokalisasi, maka prostitusi dapat difokuskan di tempat-tempat tertentu saja. Pembentukan lokalisasi akan semakin menumbuhsuburkan praktik prostitusi di seluruh daerah.

Upaya pemberian fasilitas kesehatan dan sanitasi bagi para pekerja seks juga bukanlah jalan keluar yang baik. Sebab tidak ada jaminan bahwa seluruh pekerja seks akan mengikuti prosedur yang ditentukan oleh Pemerintah Daerah. Pada sisi yang lain, pemberian fasilitas kesehatan dan sanitasi tidaklah mengangkat derajat para pekerja seksual ke derajat moralitas yang lebih baik lagi.

Pemerintah membutuhkan terobosan yang baru untuk mencegah terjadinya prostitusi sekaligus memperbaiki kondisi para pekerja seks dan prostituan seks. Beberapa solusi di bawah ini dapat dijadikan acuan untuk mewujudkan terwujudnya masyarakat yang bebas dari prostitusi. 
1. Penguatan agama dan nilai-nilai moral

Tidak dapat dipungkiri bahwa prostitusi muncul dikarenakan lemahnya pemahaman terhadap nilai-nilai keagamaan dan moralitas. Agama dan nilai-nilai moral diharapkan dapat menjadi benteng terluar dalam menolak pengaruh-pengaruh prostitusi. Pemahaman keagamaaan yang baik dan aplikasi terhadap nilai-nilai moral dalam kehidupan merupakan domain preventf terhadap ancaman prostitusi. Adapun pihak-pihak yang dapat dilibatkan dalam solusi yang pertama ini ialah para pemuka agama, tokoh adat, dan Kementerian Agama melalui penyuluh agama yang mereka miliki;

2. Penguatan ekonomi dan perbaikan mentalitas finansial

Mayoritas perbuatan prostitusi terjadi dikarenakan faktor ekonomi. Di satu sisi penyedia layanan seks berada dalam posisi kekurangaan dalam ekonomi, dan di sisi yang lain prostituan memiliki uang yang lebih untuk dibelanjakan dalam dunia prostitusi. Sehingga perlu penguatan ekonomi dari kedua belah pihak. Pada satu sisi, penyedia layanan seks harus diberikan penguatan ekonomi dari sisi pekerjaan yang layak demi kemanusiaan dan di sisi yang lain prostituan haruslah diberikan kesadaran terhadap kecerdasan finansial sehingga tidak lagi membelanjakan harta untuk kepentingan-kepentingan prostitusi. Akademisi dan para pendidik dapat dilibatkan dalam solusi yang kedua ini;

3. Pemahaman kultural

Pemahaman kultural adalah hal yang tidak kalah penting. Indonesia memiliki ragam budaya ketimuran yang sebenarnya merupakan aset yang dapat dimanfaatkan dalam membendung arus kegiatan prostitusi. Budaya timur yang lekat dengan norma kesopanan dan kesusilaan itu merupakan bagian dari norma hukum dan dapat dijadikan patokan dalam pergaulan sehari-hari. ${ }^{25}$ Pemahaman

${ }^{25}$ CST. Kansil dan Christine Kansil, Pengantar Ilmu hukum Indonesia, (Jakarta: Rineka Cipta, 2011), h. 50. kultural yang baik akan mengokohkan prinsip sebagai bangsa timur yang menjunjung tinggi budaya dan adat istiadat guna menolak prostitusi sebagai produk dari westernisasi. Pada butir solusi yang ketiga ini, budayawan dan sejarawan termasuk pula tokoh adat dapat dikedepankan;

4. Fungsionalisasi lembaga

Terdapat beberapa lembaga yang dapat berkolaborasi dalam mengatasi problematika prostitusi. Pemerintah Daerah, Dinas Tata Kota, dan Polisi Pamong Praja dapat dikategorikan sebagai lembaga preventif untuk mencegah perkembangan prostitusi di seluruh daerah. Sedangkan Dinas Sosial dan Dinas Kesehatan dapat pula difungsikan sebagai lembaga represif dalam pemberian terapi dan rehabilitasi terhadap para pekerja seks dan prostituan seks. Kepala Daerah beserta jajarannya, termasuk juga dinas dan instansi terkait dapat dikedepankan untuk mewujudkan solusi yang keempat ini.

Sinergitas keempat bidang solusi yang penulis paparkan di atas diharapkan mampu mencegah terjadinya prostitusi sekaligus menghadang perkembangan prostitusi di dalam masyarakat. Keempatnya adalah solusi yang memiliki resiko yang kecil dan berpihak kepada seluruh elemen masyarakat.

\section{Penutup}

Deklarasi Universal Hak Asasi Manusia (DUHAM) memang menggariskan pengakuan terhadap lima jenis hak asasi yang dilindungi. Akan tetapi, tidak seluruh hak asasi yang dilindungi tersebut bersesuaian dengan hak asasi manusia dalam perspektif agama Islam dan perspektif kultural (norma kesopanan dan norma kesusilaan). Kendatipun prostitusi dianggap sebagai pekerjaan atau menjadi matapencaharian sebagian kecil masyarakat, perbuatan "menjual diri” tetaplah tidak dapat diberikan toleransi sebagai right of work yang dilindungi oleh hak asasi manusia di dunia. Pun demikian dengan posisi minoritas yang dimaksudkan, seharusnya 
tidak ada perlindungan atas minoritas kecuali terhadap pemeluk agama dan keyakinan tertentu.

Islam mengajarkan kemuliaan pribadi (karamah fardhiyah) sebagai satu sendi dari tiga sendi hak asasi manusia. Berprofesi sebagai pelaku prostitusi maupun pengguna jasa layanan seks (prostituan) merupakan dua hal yang berlawanan dengan kemuliaan pribadi. Di samping itu, Islam mengupayakan perlindungan terhadap 5 (lima) prinsip hak-hak asasi manusia yaitu dharuriyyah al-khams yang terdiri dari hifz al-nafs (perlindungan atas nyawa atau jiwa), hifz al-din (perlindungan atas hak beragama), hifz al-aql (perlindungan atas akal pikiran), hifz al-maal (perlindungan terhadap harta benda), hifz al-nasl (perlindungan atas keturunan dan nama baik).

Pemerintah dapat mengambil langkah-langkah berkenaan dengan membatasi dan mencegah prostitusi. Langkah-langkah yang dimaksud merupakan sinergitas empat bidang yang meliputi: Penguatan agama dan nilai-nilai moral, penguatan ekonomi dan perbaikan mentalitas finansial, pemahaman kultural, dan fungsionalisasi lembaga.

\section{Pustaka Acuan}

Ahmad, Zainal Abidin, Piagam Madinah: Konstitusi Tertulis Pertama di Dunia, Jakarta: Pustaka Al-Kautsar, 2014.

Alam, AS., Pelacuran dan Pemerasan Studi Sosiologis Tentang Exploitasi Manusia Oleh Manusia, Bandung: Alumni, 1984. John Kenedi, "Pers dan Prostitusi", Bengkulu Ekspress, Tahun ke-2, Minggu 20 Februari 2000.

Dzahabi, Syamsuddin al-, Kitab al-Kabair, Jakarta: Syirkah Dina Mutiara Berkah Utama, t.th.
Irfan, M. Nurul, Gratifikasi \& Kriminalitas Seksual dalam Hukum Pidana Islam, Jakarta: Amzah, 2014.

Jauhar, Ahmad al-Mursi Husain, Maqashid Syariah, Jakarta: Amzah, 2010.

Kansil, ST dan Christine Kansil, Pengantar Ilmu bukum Indonesia, Jakarta: Rineka Cipta, 2011.

Kartono, Kartini, Patologi Sosial, Jakarta: RajaGrafindo Persada, 1992.

Kenedi, John, "Pers dan Prostitusi", Bengkulu Ekspress, Tahun ke-2, Minggu 20 Februari 2000.

Khanif, Ali, Hukum \& HAM, Yogyakarta: Laks Bang, 2012.

Kumkelo, Mujaid, dkk., Fiqh HAM: Ortodoksi dan Liberalisme Hak Asasi Manusia dalam Islam, Malang: Setara Press, 20115.

Ma'arif, Ahmad Syaf'i, Islam dan Masalah Kenegaraan, Jakarta: LP3ES, 1985.

Moeljatno, Kitab Undang Undang Hukum Pidana (KUHP), Jakarta: Bumi Aksara, 2001.

Qamar, Nurul, Hak Asasi Manusia dalam Negara Hukum Demokrasi (Human Rights in Democratiche Rechtstaat, Jakarta: Sinar Grafika, 2013.

Sabon, Max Boli, Hak Asasi Manusia, Jakarta: Atma Jaya, 2014.

Ubaedillah, A., dkk., Pendidikan Kewargaan (Civic Education): Demokrasi, Hak Asasi Manusia, dan Masyarakat Madani, Jakarta: ICCE UIN Jakarta dan Kencana Prenada Media Group.

Undang Undang Nomor 39 Tahun 1999 tentang Hak Asasi Manusia.

Zahid, Moh., Agama \& HAM: Dalam Kasus di Indonesia, Jakarta: Balai Penelitian dan Pengembangan Agama, Departemen Agama Republik Indonesia, 2007. 